\title{
レーザー医学一日本の現状と将来への指針
}

\author{
菊地 眞 \\ 防衛医科大学校医用電子工学講座 \\ Laser Surgery and Medicine - Status in JAPAN and Indication for the Future \\ Makoto Kikuchi \\ Department of Medical Engineering, National Defense Medical College
}

\begin{abstract}
Lasers have contributed enormously to the advancement on evolution of medicine, taking another step in the march towards and improved therapeutic condition. The Argon and frequency-doubled YAGKTP lasers both produce a green wavelength of light that can be delivered through an optical fiber. Recently some researchers use the Er:YAG laser for clinics. Short pulses from the Er:YAG have an ablative effect with little thermal damage. And also the Er:YAG offers a superior cutting tool when longer pulses are used. The Ho:YAG laser ablation with the contact irradiation method has been employed for laser angioplasty and various other clinical therapies due to the capability of the silica fiber delivery and tissue ablation. The remarkable advances and emerging technologies have been appeared in Research and developments of high-power dioed laser. They have already achieved the maximum output to approximately $60 \mathrm{~W}$ by diode laser. Sorne manufactures developed the medical systems based on the tunable laser crystal, titanium-doped sapphire. This medium lasers in the range 650-1000 nm. Frequency-conversion techniques, including a proprietary method of extending the range in the infrared, are expected to yield a device that tunes from $325-3000 \mathrm{~nm}$. This widely tunable laser may be the basis for a "universal" surgical tool that suits a variety of applications. The Japanese manufacturer(IHI Co.) developed new tunable laser consisting of YAG-OPO(Optical Prametric Oscillator) which could tune from $410-2650 \mathrm{~nm}$ wavelength.
\end{abstract}

I. レーザー医学の現状

我国におけるレーザー医学が本格化してからほぼ 20 年が経過した。現状では、基礎医学から臨床医 学の全般にわたり幅広くレーザーが使用されてい る。しかしながら、臨床現場では必ずしも満足さ れる技術にまで成熟していないのが実状と言える。 それらの最大の理由を考えてみると、レーザーの
本質的特色である単一波長性や光ファイバー導光 性など他の物理エネルギーには見られない優れた 特質が、臨床側から出される要求や満足度とかみ 合っていない「現実のづれ」によるものと考えら れる。

最近では、これまでの $\mathrm{CO}_{2}$ 、 Ar やNd-YAGレ ーザーに加えて、新たなレーザー医学を開拓する 
のにふさわしいポテンシャルの高いレーザーが 次々に登場しつつある（図 1）。第一は、半導体 レーザーの高出力化であり、これにより近赤外領 域の医用レーザーは今後大きく様変わりする可能 性が高い。さらには、これらを新たな励起光源と するレーザーダイオード励起による固体レーザー の新しい展開が急速に始まっており、全固体レー ザ (All-solidstate-laser あるいは holostelic laser とも呼ばれる）の多様化が大いに期待される。さ らには、レーザーの波長可変技術も大幅に進展し つつあり、アレキサンドライトレーザーやチタ ン・サファイアレーザーに加えて可視光から中赤 外光 $(410 \sim 2650 \mathrm{~nm})$ までの広範な波長が可変 可能な YAG-OPO (Optical Parametric Oscillator）装置も登場しており、新しいPDT 治 療やオプティカル・バイオプシー技術の今後の発 展に大きく寄与するものと期待されている（図 2)。

\section{II. 将来への展望}

今日の臨床には、きわめて多くの工学技術が日 常的に導入されている。今後の方向性としては、 益々低侵襲化が望まれることになり、レーザーも また無侵襲あるいは低侵襲手術に向けてその真価 を問われることになる。レーザーは、多くの物理 エネルギーの中で最も高いエネルギー伝送密度を 有しており、幅広い内容を包含する内視鏡下手術 を完成させ、益々低侵襲化の方向にもってゆくた めに極めて魅力的なエネルギー源である。その際 に重要なことは、たんにレーザー発振源や光ファ イバー技術を向上させるだけでなく、図 3 に示す ように洗練したレーザー治療システムを完成させ るためのより多くの周辺技術、あるいは支援技術 を併せて研究・開発しなければならないことであ る。

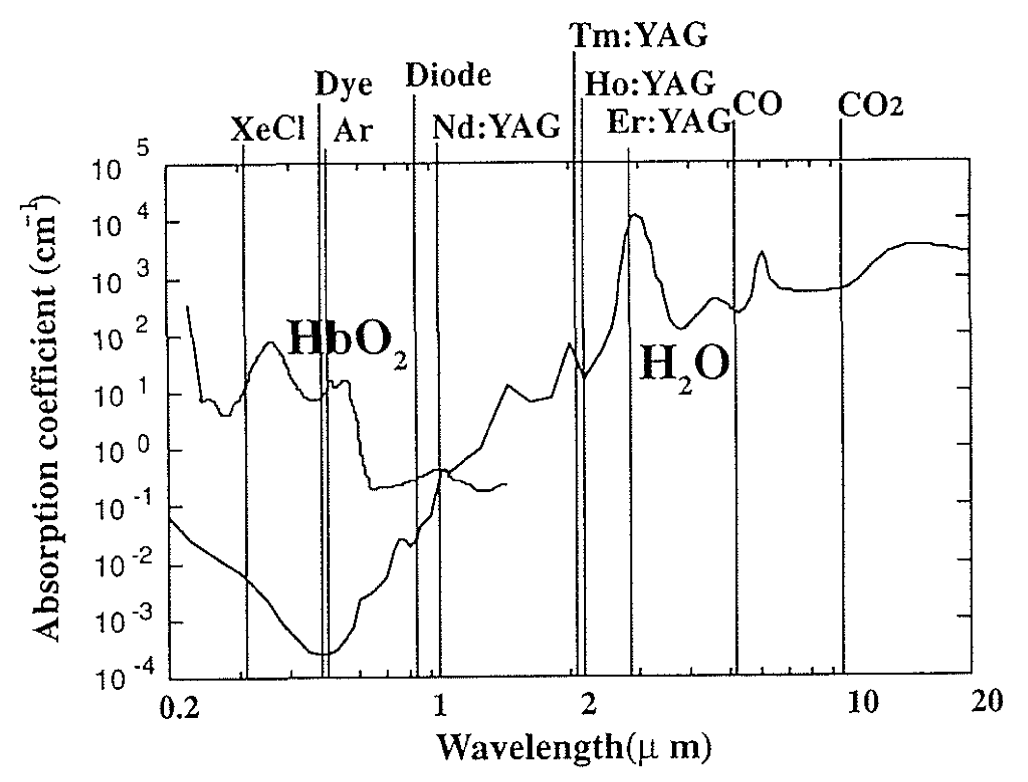

glass fiber

Chalcogenide glass

Fluoride glass

図 1 紫外光から赤外光領域まで存在する主な医用レーザーの生体組織 に対する吸収特性、および使用できる光ファイバーの種類 
一方、レーザー機器そのものがより多く臨床の 場において使用されることも、新技術を絶え間な く開発し供給する上で必須の条件になる。そのた めには、臨床家が最も使いやすいような医用レー ザー装置を製作することが必要であり、細かい部 分の切開、蒸散、凝固が一台の装置で可能なよう な小型、廉価な装置をいかに実現させるかなど生 産者側も一体となったプロジェクト開発が望まれ
さらには、「レーザーの医学的応用をより広く、か つ深く拡大させる為に、今後はたんにレーザーの 直接的応用だけでなく、前述したようなレーザー 手術の支援技術を米ね備えたレーザー治療システ ムの研究・開発や、図 5 に示すようにレーザーの 間接的応用ともいえる計測・診断技術についても 本学会で併せて議論できるよう学会としてより積 極的にそれらを吸収してゆく努力が求められよう。

る(図4)。

・固体レーザー（"固体レーザー・ルネッサンス”）

一近赤外レーザー

（半導体レーザー、LD励起固体レーザーの大出力化）

一中赤外レーザー（Er-YAG：Ho-YAG、Tm-YAGレーザー）

・多波長 (波長可変) レーザー（YAG-OPOレーザーシステム）

・導光用ファイバー

- 周辺技術

（計測技術（固体フェムト秒光源技術）、多機能マニピュレータ、 自動制御装置)

図 2 治療用レーザー装置に関する最近の技術開発動向

\section{Many kinds of maneuver, method, and adaptable care}

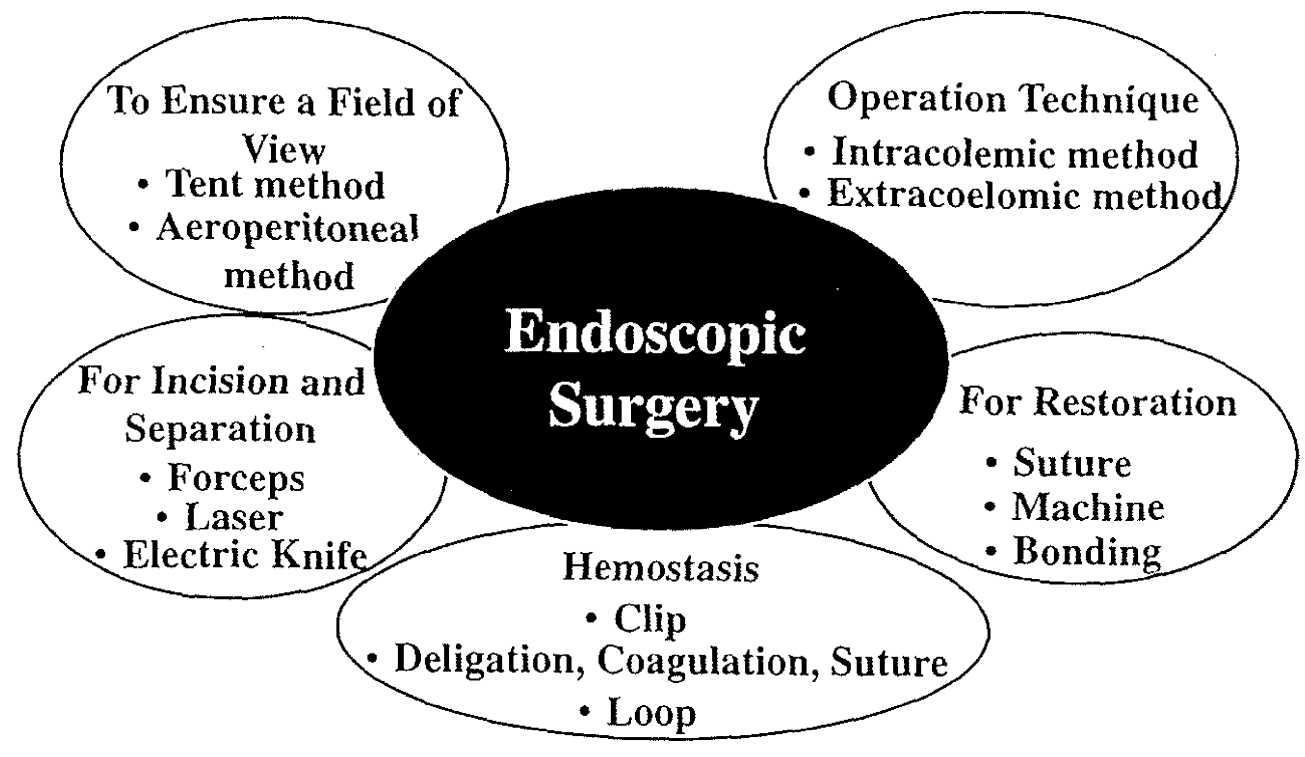

(Ikuma K, el al. Proc 17th meeting Jpn Soc Laser M

図 3 レーザー手術を支援する周辺技術の研究・開発の重要性 一内視鏡下手術を例として 
- 高性能（選択的治療効果）

，小型・軽量性（可動性、可般性）

・耐久性（メンテナンスフリー、長寿命）

・経済性（低価格、低運用コスト）

・操作性（高性能マニピュレータ）

- 多機能性 (汎用性)

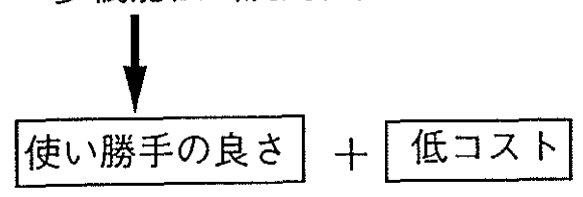

図 4 治療用レーザー装置に求められる側面

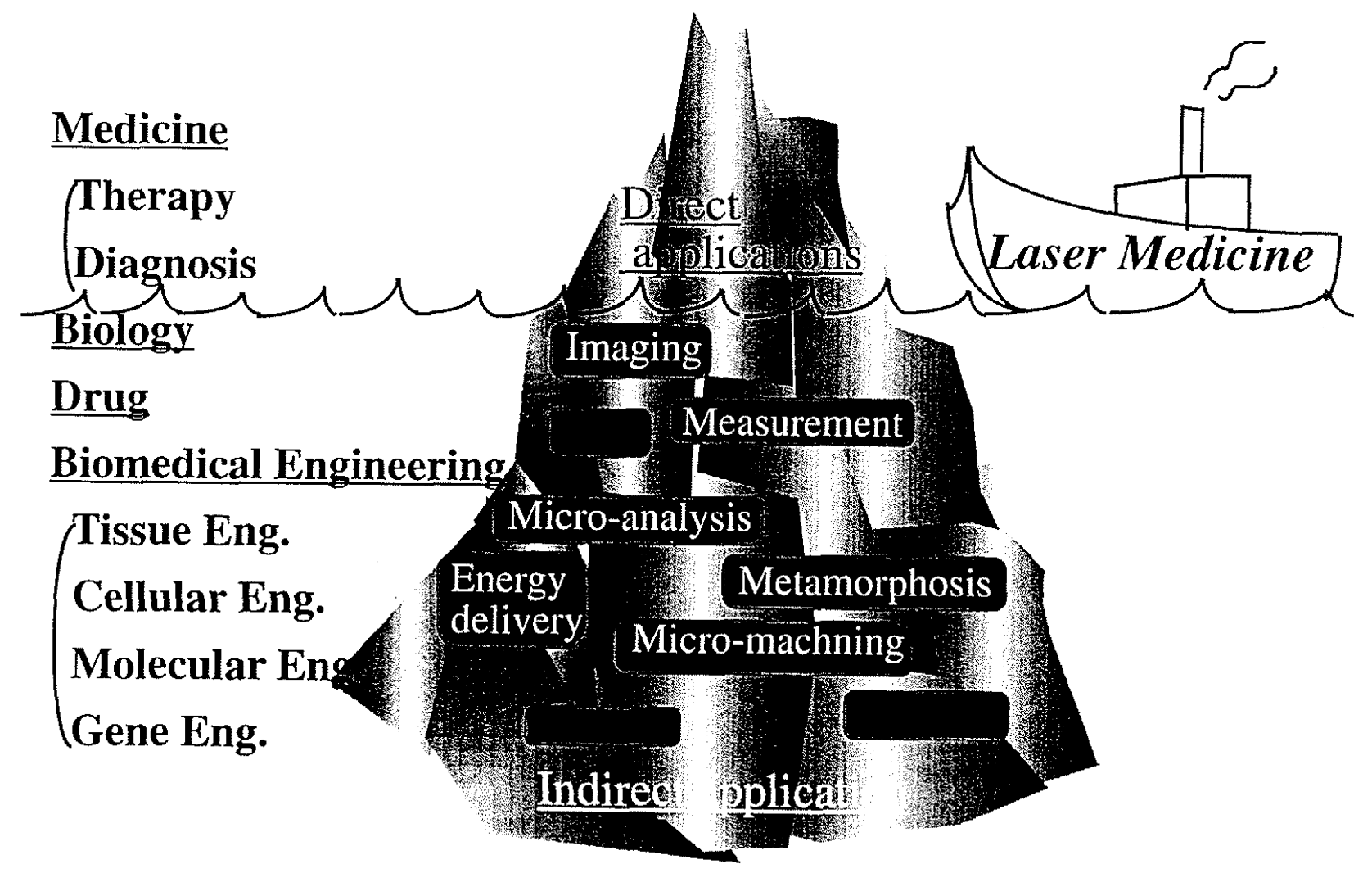

図 5 今後のレーザー医学

ーレーザーの直接的応用から間接的応用への拡がり 